\title{
EMANCIPATING THE WRITING LIFE
}

\section{Rina Angela Corpus}

\section{About the Author}

Rina Angela Corpus is an Assistant Professor of Art Studies at the University of the Philippines where she gained her BA in Art Studies and MA in Art History. She formerly danced and trained with the Quezon City Ballet and participated in workshops on Limon dance technique in New York. Her research interests include dance history, feminist aesthetics, spirituality, and gender in the arts. She has published two books about dance and art studies with the University of the Philippines Press, namely Defiant Daughters Dancing: Three Independent Women Dance (2007) and Dance and Other Slippages (2014). Her critical essays have appeared in various platforms such as Bulawan, Transit, Diliman Review, Humanities Diliman, and Philippine Humanities Review. Her research has been presented at the Congress on Research in Dance in New York. In 2012, she was a guest artist at Topaz Arts in Queens, New York. Her poems have appeared in Philippine Humanities Review, Tayo Literary Magazine, Wilde Magazine, Madswirl, and Philippines Free Press. 
Epiphanies abound in diurnal life, and Charlie Samuya Veric reminds us of the poet's persistent task of making poetry a museum of the quotidian yet contemplative existence while raising cogent issues on writing.

Veric's Histories attempts to archive and aestheticize peripatetic narratives in his first poetry collection that clearly bears a personality of its own, carrying the author's style and aesthetic. Printed in elegantly pristine and minimalist pages, appearing haiku-like on wide spaces, Veric's text carries the readers into an exposition of his poetics, which he names vernacular poetry.

Going through these pages, one is reminded of how writing is essentially a sacred act, the writer investing it with the re-telling of his devoted sojourns into self-awareness, together with his outward peregrinations. An itinerant writer, Veric refers to the locales he has visited, from his native Aklan to Diliman to New Haven and back, the various spaces that shaped his thinking and being, in the same way that he has shaped them within the frame of his lyric universe.

The book's bare and careful design, set in immaculate pages interspersed with black and white street photography by Daniel Roque, not to mention Bettina Flitner's arresting cover photo, refreshingly helps to slow down readers' attention back into a reflective mode, a respectful kind of aesthetic that does not bombard one with words and ideas, but a refreshing counterpoint in its offering of an aesthetic experience that goes against the assault of hyperimages in this age of the nanosecond. The neat, generous pages allow readers to rest into the realm of an inner space held sacred by the poet himself. Here, the writer becomes a monastic, offering us the silence of his mind, like a mirror from which our own inner lives might be glimpsed.

While monastic introversion may be one of the writer's virtues, we may well be surprised that behind this terse anthology is a compelling critique of literary cliques, one that reconsiders the systemic publish-and-perish mentality to which academe-based writers are perennially subjected. Declining the valorized glory granted to writers who have been through the traditional rites of passage such as writers' workshops, MFA programs, contests and membership in literary circles, the poet as a critical intellectual questions the culture of dependency on external institutions that have served to validate the labor of upcoming names and wannabes in the field.

Veric's critique may well apply to the art world in general, which has been influenced by Western Cartesian thought that privileges the linear and mechanistic production of art and its objects, such that art critic Suzi Gablik once called for the "re-enchantment of art" as a way of challenging the modernist paradigm of 
alienation from the artist's labor, as she gestures toward a more compassionate and relational aesthetics. In this book, Veric seems to call for the re-enchantment of the poetic life.

Championing "anti-professional poetry," Veric cries out against the systemic regimentation of writing life, and calls for one that is "untimely, ungrateful, unaffiliated." In this way, Veric calls for, however romantic and idealized, the emancipation of the writer-poet. Sans the usual legitimizing rubber stamp offered to the successful literati, sans the diurnal obligations of producing for the academic machinery, the poet may be likened to an intellectual-monastic, or perhaps, an indie thinker, relaxed in not being beholden to anyone but to himself, his own vision and voice.

This does not mean that the poet is entirely self-focused as he also keenly reflects on the ramifications of global issues in his own life. His poetic space is enlarged and intertwined with other places, accomodating relationships across time, space, and nature.

In “Open Anew, My Heart," the poet uses a news excerpt published in February 2009 as epigraph which speaks of Israel allowing the export of flowers from Gaza. This hopeful report heralding the opening of borders, as if to end the longstanding Israel-Palestinian dispute, becomes a metaphor for the poet celebrating the day, particularly on Valentine's, with the culmination of his own personal wars: "Today, I, too, will open the roads to love/and make my little wars/the stuff of parables... From where I stand, my heart will also set out-/a shipful of 25,00o carnations."

In contemplating the graceful movements of the natural world, he refers to the diasporic condition in "Song," as he recalls his brother in an Arab country, sewing clothes, "like a salmon or river:/flung, always, by flight."

In the same poem, he talks as a devoted lover of the natural world who addresses the river, valley, and infinity pool whose wonders he persistently observes: "Teach me to live the way a peak regards the sunset."

Meantime, through a prose-poetic form in "The Brave," Veric heroizes a woman who decides to walk out on her wedding day, saying: "I admire her/because she walked away from beauty."

In "A Singular Catastrophe," he speaks of his peripatetic life, moving between countries as he describes the coldness of a Madison weather, and in the same breath, the coconut trees of Manila, whose "long green fingers,/must be the envy of trees in autumn." 
The poet's focus on his navigation through time and space does not so much rave about the consumption of destinations as examine a life in constant detour and displacement. Here, he enframes the ubiquitous propensities of human beings, including himself, for things such as love, loneliness or freedom, no matter where they may be situated in this volatile planet.

So in "Parting Time," the poet speaks of a moment of no return when torn lovers must take leave, "hurtling away from paradise." Or the melancholy and desperation ensconced in "A Lonely Man Thinks" which ends with a door figuratively and entertainingly speaking to swallows, the sunlight, and a fire exit: "Walk into my life. Come. Hold my hand."

Then there is the unromantic and biting explication of a world remaining unchanged to greet one on one's "Birthday": "Tomorrow, you'll see that the world/ won't have changed for you."

Equally, there is the praise for freedom and self-confidence in the most unpredictable of scenes, as in "Looking out the Window During a Thunderstorm in Late Spring": "and the girls, unflinching,/knowing what they want:/for the doors to open,/the music to begin."

A perspicacious observer of life, at once engaged yet detached from its vicissitudes and validating systems, the poet claims a space of independence and equanimity where he can speak his mind unfettered-even as he goes on with his sojourns, deeply enamored of life's mysteries:"For in this world I quietly go,/a deer gliding deep in the woods."

Epiphanies abound in diurnal life, and Veric's Histories gestures to us that poetry need not always be beholden to legitimizing institutions to historicize and consummate them into poetic being. 